J. Amer. Soc. Hort. ScI. 117(4):551-557. 1992.

\title{
Light Environment and Time of Harvest Affect 'Delicious' Apple Fruit Quality Characteristics
}

\author{
Richard J. Campbell ${ }^{1}$ and Richard P. Marini \\ Department of Horticulture, Virginia Polytechnic Institute and State University, Blacksburg, \\ VA 24061
}

Additional index words. Malus domestica, photosynthetic photon flux density, fruit weight, soluble solids concentration, fruit red pigmentation

\begin{abstract}
Photosynthetic photon flux density (PPFD), measured at various canopy positions throughout the growing season in 1989 and 1990, was used to explain variation in fruit characteristics of 'Delicious' apples (Malus domestica Borkh.) harvested from these positions at 135, 145, 155, and 165 days after full bloom (DAFB). Hours above an average PPFD threshold of $250 \mu \mathrm{mol} \cdot \mathrm{m}^{-2} \cdot \mathrm{s}^{-1}\left(\mathrm{HR}_{250}\right)$ explained an average of only $2 \%$ more variation in fruit characteristics than other PPFD threshold levels or total cumulative photosynthetic photon density (PPD) in each year. Percent of red surface had a positive linear relationship with $\mathbf{H R}_{250}$ on all harvest dates in both years; intercepts increased on each successive harvest. The slopes and $R^{2}$ were highest at 135 DAFB and decreased on each successive harvest. Intensity of red pigmentation and soluble solids concentration also increased linearly with $\mathbf{H R}_{250}$, with equivalent slopes and increasing intercepts on each successive harvest. Fruit weight, flesh firmness, length : diameter ratio, and starch index were not consistently affected by any measure of canopy light levels. Except for intensity of redness, relationships developed between fruit characteristics and cumulative late-season PPD during the final 10 weeks before harvest $\left(\mathrm{CPPD}_{\mathrm{LS}}\right)$ had trends similar to the models for $\mathrm{HR}_{250}$ for all harvests in both years. Models developed with instantaneous light measurements were similar to those developed with the more detailed cumulative light measurements.
\end{abstract}

The light environment influences fruit quality, including red pigmentation, soluble solids concentration, and fruit weight. However, these data are largely the result of imposed shade studies (Doud and Ferree, 1980; Jackson and Palmer, 1977; Marini et al., 1991; Patten and Proebsting, 1986; Robinson et al., 1983; Seeley et al., 1980), which do not accurately represent the natural shading conditions within a plant canopy. Most studies on the influence of the natural canopy light environment on fruit quality have been conducted in arid climates with predominantly cloudless conditions during the growing season (Barritt et al., 1987; Heinicke, 1966; Morgan et al., 1984; Patten and Proebsting, 1986; Southwick et al., 1990; Tustin et al., 1988). Relationships developed in arid regions between fruit quality characteristics and light levels may not be directly applicable to humid regions, as there maybe differences in canopy light intensity between the two regions due to differences in diffuse light exposure (Heinicke, 1967; Lakso and Musselman, 1976).

Programmable dataloggers and inexpensive silicon photocell sensors provide an affordable method of quantifying light levels at many specific canopy positions throughout the growing season, and unlike the integrative methods used by Heinicke (1963), these measurements are not confounded by spectral changes within the canopy, because the silicon photocell sensors measure only photosynthetically active radiation. In addition, the light measurements from these specific canopy positions can be expressed in a variety of ways for comparison with fruit quality measurements.

The objectives of this study were to use detailed light measurements (measured in either terms of hour or energy units) from multiple canopy positions to explain the variation in apple

Received for publication 19 Feb. 1992. Accepted for publication 11 Mar. 1992. The cost of publishing this paper was defrayed in part by the payment of page charges. Under postal regulations, this paper therefore must be hereby marked advertisement solely to indicate this fact.

${ }^{1}$ To whom correspondence and reprint requests should be addressed. Present address: Research Center, Fairchild Tropical Garden, 11935 Old Cutler Rd. Miami, FL 33156. fruit quality characteristics at each position, and to determine how harvest date interacts with these relationships. A second experiment was conducted to validate and compare the use of estimated light levels derived from instantaneous measurements to explain variation in fruit quality characteristics of fruit from different canopy positions.

\section{Materials and Methods}

Orchard. The study was conducted with 15-year-old 'Red Prince Delicious'/MM.111 trees growing on the Virginia Polytechnic Institute and State Univ. Horticulture Farm, B1acksburg. Rows were oriented in an east-west direction, with inrow and between-row spacings of 5.5 and $6.1 \mathrm{~m}$, respectively. Average tree height and width were 5.4 and $4.8 \mathrm{~m}$, respectively, with an average trunk circumference of $60 \mathrm{~cm}$. Yield efficiency in both years was reduced by spring frost, and was 0.82 and $0.68 \mathrm{~kg} \cdot \mathrm{cm}^{-2}$ trunk cross-sectional area in 1989 and 1990, respectively. Full bloom for both years was 20 Apr.

Light sensor construction. Silicon photocell sensors were constructed according to the design of Grappadelli and Coston (1988). These sensors consisted of a silicon photocell (Texas Optoelectronics, Garland, Texas), a selective glass filter that excluded wavelengths above and below 400 to $700 \mathrm{~nm}$ (B638, Schott Optical Glass, Duryea, Pa.), a diffusive plexiglass top, and a clear plexiglass body covered in black-plastic electrician's tape, except for a $1 \times 2-\mathrm{cm}$ window directly above the filter and sensor. These sensors were cosine-correcting and responded similarly when compared with a quantum sensor (Model LI190SB, LI-COR, Lincoln, Neb.) over a range of light levels (Grappadelli and Coston, 1988). Sensors were connected to a Campbell Scientific $21 \times$ datalogger (Campbell Scientific, Logan, Utah) through a 32-channel multiplexer (Campbell Scientific).

Canopy position and harvest date effects (Expt. 1). Twentytwo sensors were placed in close proximity to fruiting spurs

Abbreviations: DAFB, days after full bloom; FS, full sun; FW, fruit weight; $\mathrm{L}$ : D, length : diameter ratio; PPD, photosynthetic photon density PSR, percentage surface red; SSC, soluble solids concentration. 
within the canopy of a single 'Delicious' tree in 1989. Positions were chosen to provide a wide range of light levels; the sensors were not in a grid pattern. The sensors were taped to wood strips nailed at varying heights onto five 4.6-m-high, $5 \times 10$ $\mathrm{cm}$ wooden boards (three to five sensors per board). The five boards were placed within the canopy of the tree, one within $50 \mathrm{~cm}$ of the south side of the trunk and the remaining four in either the northeast, northwest, southeast, or southwest quadrants of the tree, respectively, $\approx 50$ to $100 \mathrm{~cm}$ from the periphery of the canopy. All sensors were oriented toward the southern side of the board to avoid shading from the board itself. Sensors were periodically leveled. For incident photosynthetic photon flux density (PPFD) measurements and comparison of the two sensor types, one silicon photocell sensor and one quantum sensor (Model LI190SB) were placed side-by-side on a board 4.6 $\mathrm{m}$ above the ground in the row where two trees had been removed. The datalogger was programmed to scan each sensor and record PPFD every $10 \mathrm{sec}$. These values were then summed over 5-min periods to get a photosynthetic photon density (PPD) in quantum units $\left(\mathrm{mol} \cdot \mathrm{m}^{-2}\right)$. Measurements were made from 22 July-4 Oct. 1989.

Fruit were harvested within $30 \mathrm{~cm}$ of each sensor at 135, 145, 155 , and 165 days after full bloom (DAFB). One spur with a single fruit and one spur with two fruit were selected on each harvest date to provide a total of three fruit per position per date in 1989. Fruit weight $(\mathrm{FW})$ and length : diameter $(\mathrm{L}: \mathrm{D})$ ratio were determined for each fruit. Percent surface red (PSR) was visually evaluated. Flesh firmness was measured with an Effigi firmness tester fitted with a 11.1-mm plunger (Model FT 327; McCormick Fruit Tech, Yakima, Wash.) on the green and the red sides of the fruit and averaged for a single value. Soluble solids concentration (SSC) was measured with an Atago model N-1 hand-held refractometer (McCormick Fruit Tech). Fruit were cut in half and rated with a published index for starch content with an iodine solution on a scale of 1 to 9 (immature to overmature) and the number of seeds was recorded. Water core was evaluated on a scale of 1 to 8 (none to severe) and the presence of moldy core was noted.

In 1990, 15 sensors were placed in the same manner within the canopies of two trees ( 30 total sensors). The datalogger was programmed to record PPFD every $10 \mathrm{sec}$ as in the previous year, but data were summed to 15 -min PPD totals. Measurements were made for the entire growing season, from 23 Mar.4 Oct. 1990. Fruit were hand-thinned at a 6- to 8 -mm diameter to a single fruit per spur. Single fruit were not necessarily derived from the king bloom because spring frost had killed much of the king bloom. Three fruit within $30 \mathrm{~cm}$ of each sensor were randomly selected, each at $135,145,155$, and 165 DAFB. Fruit quality measurements were as in 1989 except the A : B ratio or intensity of red color (INT) was also measured on the red side of each fruit with a Minolta Chroma meter model CR-200b (Minolta, Ramsey, N.J.). The data for 165 DAFB in both years were similar to 155 DAFB and are not presented.

Validity of instantaneous measurements (Expt. 2). Six additional 'Delicious'/MM.111 trees were used in 1990. Five canopy positions were chosen per tree to achieve a range of light levels for the development of regression relationships. Position 1 was located at the top of the tree within 30 to $60 \mathrm{~cm}$ of the canopy periphery and within $50 \mathrm{~cm}$ of the central leader. Position 2 was located 150 to $200 \mathrm{~cm}$ below position 1 . Position 3 was located at the interior of the canopy $\approx 480$ to $520 \mathrm{~cm}$ below position 1 . Position 4 was located at the lower middle canopy at a height of $\approx 150 \mathrm{~cm}$ above the ground and 150 to
$200 \mathrm{~cm}$ from the canopy periphery. Position 5 was located on the canopy periphery at a height of $\approx 150 \mathrm{~cm}$ above the ground. All five positions were in the southwest quadrant of the tree.

Five fruit were harvested from within $50 \mathrm{~cm}$ of each of the five canopy positions per tree at 135, 145, 155, and 165 DAFB. Therefore, a total of 30 fruit was harvested per position per date, and only spurs with single fruit were selected. Fruit quality measurements were conducted as in expt. 1. PPFD was measured at each canopy position per tree per date on the first overcast day following each harvest (within 6 days) with a Lambda quantum sensor (LI-COR, Model LI-185). Four measurements were made at each position, averaged, and divided by the incident PPFD measured next to each tree in a fully exposed position to calculate a proportion of the incident PPFD. These proportions were then multiplied by the cumulative late-season (22 July to harvest) PPD from the reference sensor used in expt. 1 (within $70 \mathrm{~m}$ of these trees) to estimate cumulative late-season PPD $\left(\mathrm{CPPD}_{\mathrm{LS}}\right)$ in quantum units $\left(\mathrm{mol} \cdot \mathrm{m}^{-2}\right)$.

Statistical analysis. Regression analysis (SAS, 1985) was used to relate fruit quality characteristics with PPFD measurements in expt. 1. Linear, quadratic, and nonlinear models were tested. Individual observations (fruit) rather than means of multiple fruit per sensor position were used to develop regression models. Cumulative late-season PPD measured from 22 July to harvest $\left(\mathrm{CPPD}_{\mathrm{LS}}\right)$, cumulative total-season PPD measured from 23 Mar. to harvest $\left(\mathrm{CPPD}_{\mathrm{TS}}\right)$, and for FW cumulative early season PPD measured from petal fall $(\mathrm{PF})$ to $\mathrm{PF}+45$ days $\left(\mathrm{CPPD}_{\mathrm{ES}}\right)$ were used as regressor variables for explaining variation in fruit quality characteristics. Also, hours above various average PPFD threshold levels were used as regressor variables by summing the number of 5- or 15-min (depending on year) time periods that averaged greater than some designated PPFD level. PPFD threshold levels of 100 to $1000 \mu \mathrm{mol} \cdot \mathrm{m}^{-2} \cdot \mathrm{s}^{-1}$, at increments of 50, were tested. In 1989 for FW, separate relationships were developed for the single and double fruit per spur, as these were determined to be distinct populations $(P<0.05)$. For Expt. 2 in 1990, fruit quality characteristics were regressed against the estimated $\mathrm{CPPD}_{\mathrm{LS}}$. Models for both experiments were compared to each other with indicator (dummy) variables in multiple regression (Montgomery and Peck, 1982).

\section{Results and Discussion}

Expression of light levels. The use of threshold PPFD levels instead of cumulative PPD totals has biological relevance because physiological activities in apple trees, including net photosynthesis (Barden, 1977) and red pigmentation development of the fruit (Saks et al., 1990), were shown to have threshold PPFD levels above which additional PPFD had no added effect. By using the amount of time above certain PPFD thresholds, equal weight was given to any PPFD level above the threshold. We tested average PPFD threshold levels of 100 to 1000 umol $\cdot \mathrm{m}^{-2} \cdot \mathrm{s}^{-1}$ because we hypothesized that the threshold PPFD level could differ, depending on the fruit quality characteristic being considered. Saks et al. (1990) demonstrated that red pigment development had a threshold PPFD level of $\approx 150$ $\mu \mathrm{mol} \cdot \mathrm{m}^{-2} \cdot \mathrm{s}^{-1}$; whereas SSC should presumably have a higher threshold due to its dependence on photosynthesis. However, we found that the threshold level of $250 \mu \mathrm{mol} \cdot \mathrm{m}^{-2} \cdot \mathrm{s}^{-1} \mathrm{w}$ as superior for all fruit quality characteristics (data not presented).

Total hours above an average PPFD threshold level of 250 $\mu \mathrm{mol} \cdot \mathrm{m}^{-2} \cdot \mathrm{s}^{-1}\left(\mathrm{HR}_{250}\right)$ explained an average of only $\approx 2 \%$ more of the variation in the fruit characteristics (Figs. 1 and 2) than $\mathrm{CPPD}_{\mathrm{LS}}($ Tables 1 and 2). Among the cumulative PPD 

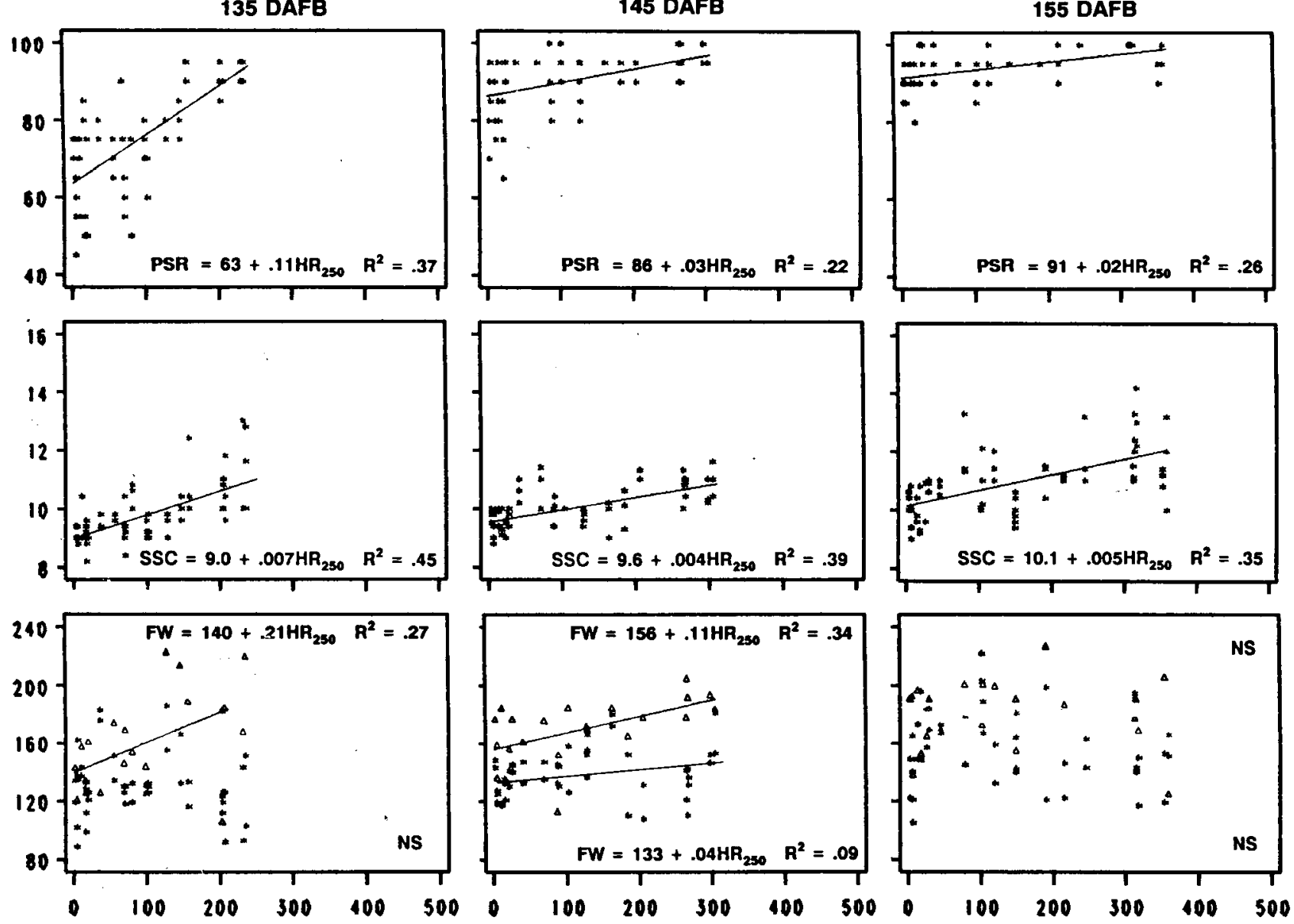

Hours above an average PPFD threshold of $250 \mu \mathrm{mol} \cdot \mathrm{m}^{-2} \cdot \mathrm{sec}^{-1}\left(\mathrm{HR}_{250}\right)$

Fig. 1. Relationships between PSR, SSC, FW, and the number of hours above an average PPFD threshold level of $250 \mu \mathrm{mol} \cdot \mathrm{m}^{-2} \cdot \mathrm{s}^{-1}\left(\mathrm{HR}_{250}\right)$ for 'Delicious' fruit harvested at 135, 145, and 155 DAFB in 1989. For FW, model in upper right corresponds to data for single-fruit spurs $(\Delta)$, and model in lower right corresponds to data for two-fruit spurs $(*)$. All regressions were significant at $P<0.05(\mathrm{n}=66)$.

measures tested, models developed with $\mathrm{CPPD}_{\mathrm{LS}}$ (Tables 1 and 2) explained as much or more of the variation in the fruit quality characteristics as the $\mathrm{CPPD}_{\mathrm{TS}}$, or $\mathrm{CPPD}_{\mathrm{ES}}$ models (data not presented). All of the measures used to quantify light levels within the canopy were closely correlated with each other; for example, $\mathrm{HR}_{250}$ and $\mathrm{CPPD}_{\mathrm{LS}}$ had correlation coefficients $>0.97$ on all dates in both years. Thus, differences in the amount of variation explained by each of the expressions of light were usually $<5 \%$.

Fruit red pigmentation. PSR had a positive linear relationship with $\mathrm{HR}_{250}$ on all harvest dates in 1989 (Fig. 1) and in 1990 (Fig. 2). Models for 1990 generally had smaller slopes than in 1989, but slopes on a given harvest date did not differ between years. With each progressive harvest date within each year, the models had higher intercepts and lower slopes, and the $R^{2}$ generally declined. At 135 DAFB, in 1990, $12 \mathrm{~h}$ of average PPFD levels $>250 \mu \mathrm{mol} \cdot \mathrm{m}^{-2} \cdot \mathrm{s}^{-1}\left(\mathrm{HR}_{250}\right)$ were required for a $1 \%$ increase in PSR, but by 155 DAFB, $165 \mathrm{~h}$ of $\mathrm{HR}_{250}$ were required for a $1 \%$ increase in the PSR. By 155 DAFB, the intercept reached a maximum value of $\approx 91 \%$ and $96 \%$ PSR for 1989 and 1990, respectively. The slopes were much lower on this date, particularly in 1990. The relationships between PSR and $\mathrm{CPPD}_{\mathrm{LS}}$ had a similar trend to those for $\mathrm{HR}_{250}$, but they were more variable (Tables 1 and 2). We tested exponential (nonlinear) models were tested on the PSR data but did not judge them superior to linear models based on goodness-of-fit (data not presented).

For both years, no more than $38 \%$ of the variation in PSR was explained by $\mathrm{HR}_{250}$, and the best relationships were for 135 DAFB. Multiple regression was performed with the stepwise procedure (SAS, 1985) using linear and quadratic terms of $\mathrm{HR}_{250}$ and SSC and an interaction term $\left(\mathrm{HR}_{250} * \mathrm{SSC}\right)$ to explain the variation in PSR. The model, PSR $(\%)=-309+69 \mathrm{SSC}-$ $3 \mathrm{SSC}^{2}+0.0003 \mathrm{HR}_{250}{ }^{2}$, explained $51 \%$ of the variation in PSR on 135 DAFB in 1989. In 1990, the model, PSR $(\%)=$ $-185+24 \mathrm{SSC}+0.86 \mathrm{HR}_{250}-0.07 \mathrm{SSC}^{*} \mathrm{HR}_{250}$, explained $52 \%$ of the variation in PSR. The additional variation in PSR explained by including the SSC term in the multiple regression model was probably because, in addition to its relationship with light level, soluble solids are precursors for anthocyanin in apple (Siegelman and Hendricks, 1958). Shading from spur leaves and adjacent fruit or branches probably contributed to the unexplained variation in PSR. Temperature differences among the positions could also have influenced the PSR by influencing anthocyanin synthesis (Siegelman and Hendricks, 1958).

Suppression of red pigmentation by imposed-shade treatments has been well documented in 'Delicious' (Robinson et al., 1983; Seeley et al., 1980) and other apple cultivars (Proctor and Creasy, 

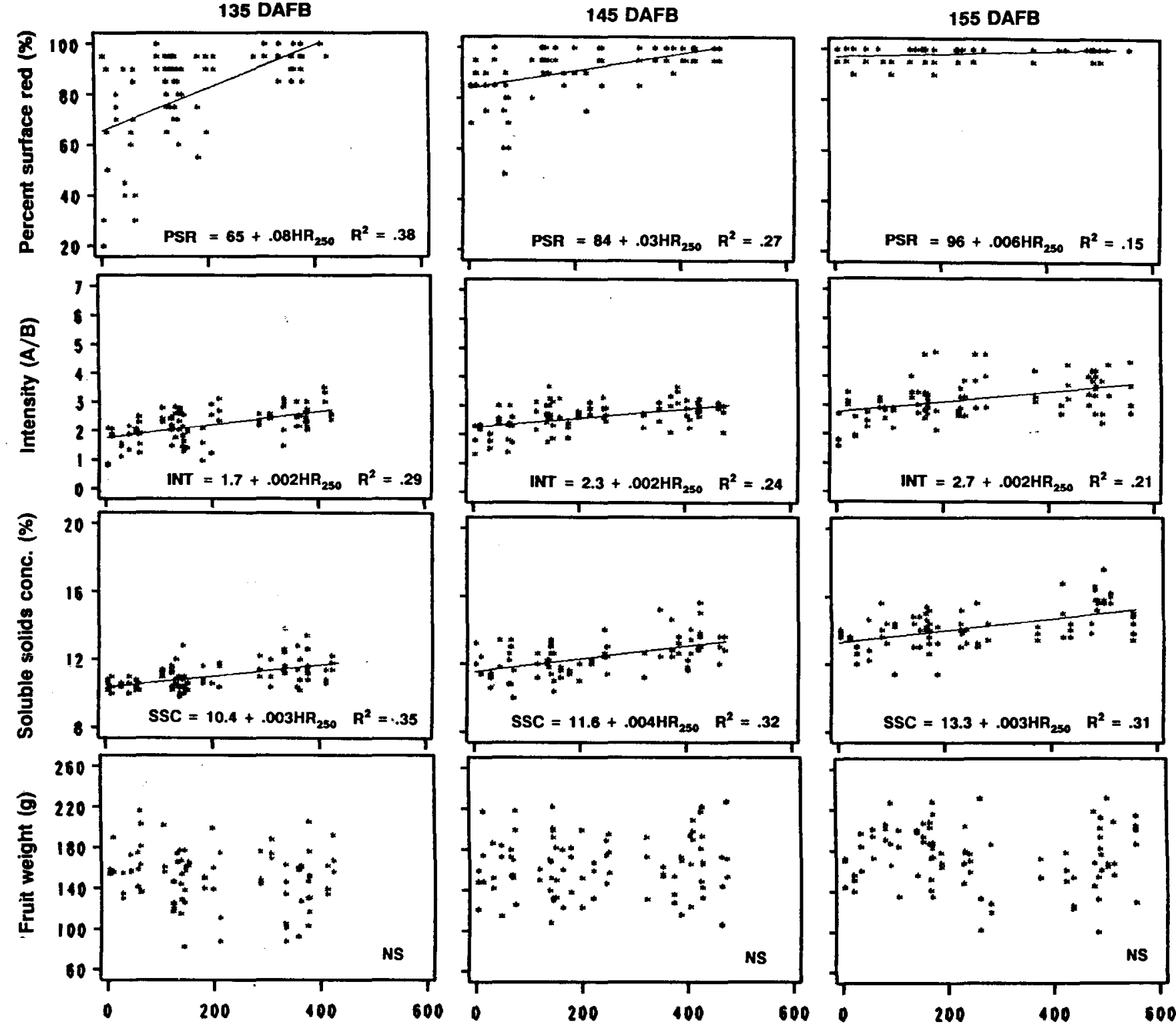

Hours above an average PPFD threshold of $250 \mu \mathrm{mol} \cdot \mathrm{m}^{-2} \cdot \mathrm{sec}^{-1}\left(\mathrm{HR}_{250}\right)$

Fig. 2. Relationship between PSR, red color intensity (INT), SSC, FW, and the number of hours above an average PPFD threshold level of $250 \mu \mathrm{mol} \cdot \mathrm{m}^{-2} \cdot \mathrm{s}^{-1}$ for 'Delicious' fruit harvested at 135,145 , and $155 \mathrm{DAFB}$ in 1990 . All regressions were significant at $P<0.05(\mathrm{n}=$ $90)$.

Table 1. Regression models for the relationship between PSR, SSC, FW, and cumulative late-season PPD levels in moles per square meter (CPPD $\mathrm{LS}_{\mathrm{LS}}$ ) for 'Delicious' in 1989."

\begin{tabular}{|c|c|c|c|c|c|c|}
\hline & 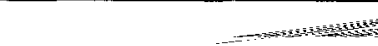 & $\operatorname{sen}$ & 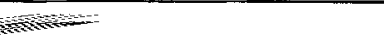 & & & \\
\hline rrult qually & 0 & & 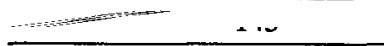 & $\ldots$ & $\ldots$ & \\
\hline characteristic & Model & $R^{2}$ & Model & $R^{2}$ & Model & $R^{2}$ \\
\hline PSR & PSR $=63+0.02$ CPPD $_{2 s}$ & 0.31 & $\mathrm{PSR}=85+0.009 \mathrm{CPPD}$ & 0.22 & $\mathrm{PSR}=91+0.005 \mathrm{CPPD}$ & 0.24 \\
\hline Drans & Now & $x$ & $\ldots$ & $\ldots$ & -1 & 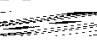 \\
\hline 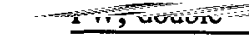 & Hos & 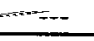 & $+H-1,1 T$ T.U1CUNALLS & 0.08 & ivo & -- \\
\hline
\end{tabular}

1971; Proctor and Lougheed, 1976). Heinicke (1966) reported that PSR development was closely related to the light level in the immediate vicinity of 'Turner Delicious' fruit within the canopy. The best degree of redness developed when fruit were exposed to $>70 \%$ full sun (FS), with adequate color development between $40 \%$ to $70 \% \mathrm{FS}$ and inadequate color development below $40 \%$ FS. Our data showed wide variation in PSR at light levels below $20 \%$ to $30 \%$ of incident, with the poorest- 
Table 2. Regression models for the relationship between PSR, intensity of red color (INT), SSC, FW, and cumulative late-season PPD levels in moles per square meter $\left(\mathrm{CPPD}_{\mathrm{LS}}\right)$ for 'Delicious' in $1990{ }^{\mathrm{z}}$

\begin{tabular}{|c|c|c|c|c|c|c|}
\hline \multirow{3}{*}{$\begin{array}{l}\text { Fruit quality } \\
\text { characteristic }\end{array}$} & \multicolumn{6}{|c|}{ Days after full bloom } \\
\hline & \multicolumn{2}{|l|}{135} & \multicolumn{2}{|l|}{145} & \multicolumn{2}{|l|}{155} \\
\hline & Model & $R^{2}$ & Model & $R^{2}$ & Model & $R^{2}$ \\
\hline $\begin{array}{l}\text { PSR } \\
\text { INT } \\
\text { SSC } \\
\text { FW } \\
\end{array}$ & $\begin{array}{c}\mathrm{PSR}=63+0.03 C P P D_{L S} \\
\mathrm{INT}=1.6+0.001 C P P D_{L S} \\
\mathrm{SSC}=10.3+0.001 C P P D_{L S} \\
\text { NS }\end{array}$ & $\begin{array}{c}0.37 \\
0.33 \\
0.23 \\
-\cdots \\
\end{array}$ & $\begin{array}{c}\mathrm{PSR}=83+0.01 \mathrm{CPPD} \mathrm{DS}_{\mathrm{LS}} \\
\mathrm{INT}=2.2+0.0006 \mathrm{CPPD} \mathrm{LS}_{\mathrm{LS}} \\
\mathrm{SSC}=11.5+0.001 \mathrm{CPPD} \mathrm{L}_{\mathrm{LS}} \\
\mathrm{NS}\end{array}$ & $\begin{array}{c}0.24 \\
0.23 \\
0.27 \\
--- \\
\end{array}$ & $\begin{array}{c}\mathrm{PSR}=97+0.002 \mathrm{CPPD}_{\mathrm{LS}} \\
\mathrm{INT}=2.7+0.0007 \mathrm{CPPD} \mathrm{LS}_{\mathrm{LS}} \\
\mathrm{SSC}=13.2+0.001 \mathrm{CPPD} \\
\mathrm{NS}\end{array}$ & $\begin{array}{l}0.14 \\
0.19 \\
0.27 \\
---\end{array}$ \\
\hline
\end{tabular}

${ }^{\mathrm{z}}$ All models are significant at $P<0.05(\mathrm{n}=90)$.

Table 3. Regression models for the relationship between PSR, intensity of red color (INT), SSC, FW, and estimated cumulative lateseason PPD levels in moles per square meter $\left(\mathrm{CPPD}_{\mathrm{LS}}\right)$ for 'Delicious' in $1990 .{ }^{\mathrm{Z}} \mathrm{CPPD}_{\mathrm{LS}}$ calculated from a single measurement on a uniformly overcast day.

\begin{tabular}{|c|c|c|c|c|c|c|}
\hline \multirow{3}{*}{$\begin{array}{l}\text { Fruit quality } \\
\text { characteristic }\end{array}$} & \multicolumn{6}{|c|}{ Days after full bloom } \\
\hline & \multicolumn{2}{|l|}{135} & \multicolumn{2}{|l|}{145} & \multicolumn{2}{|l|}{155} \\
\hline & Model & $R^{2}$ & Model & $R^{2}$ & Model & $R^{2}$ \\
\hline $\begin{array}{l}\text { PSR } \\
\text { INT } \\
\text { SSC } \\
\text { FW } \\
\end{array}$ & $\begin{array}{c}\mathrm{PSR}=61+0.03 C \mathrm{CPPD}_{\mathrm{LS}} \\
\mathrm{INT}=1.5+0.001 \mathrm{CPPD}_{\mathrm{LS}} \\
\mathrm{SSC}=10.6+0.002 \mathrm{CPPD}_{\mathrm{LS}} \\
\mathrm{NS}\end{array}$ & $\begin{array}{c}0.29 \\
0.29 \\
0.33 \\
--.\end{array}$ & $\begin{array}{c}\mathrm{PSR}=83+0.01 \mathrm{CPPD}_{\mathrm{LS}} \\
\mathrm{INT}=2.2+0.0005 \mathrm{CPPD}_{\mathrm{LS}} \\
\mathrm{SSC}=11.2+0.002 \mathrm{CPPD}_{\mathrm{LS}} \\
\mathrm{NS}\end{array}$ & $\begin{array}{l}0.21 \\
0.20 \\
0.29 \\
---\end{array}$ & $\begin{array}{c}\mathrm{PSR}=97+0.001 \mathrm{CPPD}_{\mathrm{LS}} \\
\mathrm{INT}=2.8+0.0004 \mathrm{CPPD}_{\mathrm{LS}} \\
\mathrm{SSC}=12.9+0.001 \mathrm{CPPD}_{\mathrm{LS}} \\
\mathrm{NS}\end{array}$ & $\begin{array}{c}0.15 \\
0.15 \\
0.32 \\
-.-\end{array}$ \\
\hline
\end{tabular}

${ }^{\mathrm{z}}$ All models are significant at $P<0.05(\mathrm{n}=150)$.

colored fruit but also highly colored fruit present at these positions.

Differences in coloring potential among 'Delicious' strains may explain why Barritt et al. (1987) reported no correlation between light level and PSR of 'Oregon Spur Delicious', while light level was related to PSR of 'Turner Delicious' (Heinicke, 1966) and 'Red Prince Delicious' in our study. Most recently planted 'Delicious' orchards in Virginia are of high-coloring 'Delicious' strains, but there is still significant 'Delicious' hectareage of relatively low-coloring strains in our region (R.P.M., personal observation). Harvest date clearly influenced the importance of light levels on PSR. Even fruit at the lowest light levels within our canopy developed $\approx 90 \%$ red surface by 155 DAFB. For our conditions, 145 DAFB would probably be optimal for long-term storage of 'Red Prince Delicious'.

Intensity of redness also had a positive linear relationship with $\mathrm{HR}_{250}$ in 1990 (Fig. 2). Intercepts were higher on each successive harvest date, but the slopes were equivalent for all harvest dates. Therefore, even though the relationship between PSR and $\mathrm{HR}_{250}$ weakened and had progressively lower slopes on the later harvest dates, the relationship between intensity of redness and $\mathrm{HR}_{250}$ remained consistent through 155 DAFB. However, when intensity of redness was regressed against $\mathrm{CPPD}_{\mathrm{LS}}$, the trend was similar to that found with PSR, where the slopes became progressively lower on the successive harvest dates (Table 2). This was the only instance where the expression of light $\left(\mathrm{HR}_{250}\right.$ vs. $\mathrm{CPPD}_{\mathrm{LS}}$ ) consistently altered the overall trend in models for the four harvest dates. Intensity of red pigmentation may be a better indicator of incident light levels than PSR, because the relationships, with light levels $\left(\mathrm{HR}_{250}\right)$ were more consistent over a longer harvest interval. High-coloring 'Delicious' strains may not respond in the same manner as the moderate-coloring 'Red Prince Delicious'.

Soluble solids concentration. SSC had a positive linear relationship with $\mathrm{HR}_{250}$ in both years on all harvest dates. Intercepts increased on each successive harvest in both years, and in 1990, SSC (intercepts) were higher than in 1989 (Figs. 1 and 2). In 1989, there was a steeper slope at 135 DAFB, with equiv- alent slopes at 145 and 155 DAFB. Slopes were equivalent on all harvest dates in 1990. Therefore, unlike PSR, additional $\mathrm{HR}_{250}$ resulted in similar relative increases in SSC on the successive harvest dates, although the minimum SSC level (intercept) increased. $\mathrm{HR}_{250}$ explained $45 \%$ and $35 \%$ of the variation in SSC in 1989 and 1990, respectively, at 135 DAFB; variation increased (lower $R^{2}$ ) on subsequent harvest dates for both years. Positive linear relationships were also found for SSC and $C P P D_{L S}$ on all dates in both years, with similar trends across all harvest dates when compared with the $\mathrm{HR}_{250}$ relationships (Table 2).

Imposed-shade treatments applied to entire trees or scaffold branches suppressed SSC by up to $22 \%$ (Doud and Ferree, 1980; Robinson et al., 1983; Seeley et al., 1980). In addition to shading the immediate vicinity of the fruit, shoot leaves were also shaded, possibly enhancing the suppression of SSC. The importance of the shoot leaves for the accumulation of SSC in the fruit within the canopy was demonstrated in summer pruning experiments with apple (Marini and Barden, 1982; Morgan et al., 1984). Therefore, shading in the immediate vicinity of the fruit may be partially compensated for by translocated assimilates from the better-exposed portions of the canopy (exterior shoot leaves), as was shown within peach [Prunus persica (L.) Batsch.] canopies (Marini et al., 1991).

Suppression of SSC in our study from the high to the low light levels based on the regression equations was $\approx 11 \%$ to $15 \%$ in 1989 , and $10 \%$ to $14 \%$ in 1990 , which generally agreed with previous studies with apple (Barritt et al., 1987; Ferree, 1989; Heinicke, 1966). Based on imposed shading, Seeley et al. (1980) indicated that light levels capable of producing commercially acceptable red pigmentation may not result in adequate SSC, particularly in high-coloring 'Delicious' strains. However, our results indicate that, with 'Red Prince Delicious', there was a greater suppression in PSR than in SSC over the same range of light levels on the early harvests (135, 145 DAFB) (Figs. 1 and 2). By 155 DAFB, our results agreed more closely with results from the high-coloring strains.

Fruit weight. Fruit weight data were separated into spurs with single fruit and spurs with two fruit in 1989 (Fig. 1). The data 
for single-fruit spurs had a positive linear relationship with $\mathrm{HR}_{250}$. on 135 and $145 \mathrm{DAFB}$, with a nonsignificant relationship by 155 DAFB. The double-fruit spurs had a weak, significant, positive linear relationship on 145 DAFB, but not on the other dates. When these data were pooled, there was no relationship between $\mathrm{FW}$ and $\mathrm{HR}_{250}$ on any harvest date (data not presented). In 1990 , bias due to several fruit per spur was removed by handthinning, and there was no relationship between $\mathrm{FW}$ and $\mathrm{HR}_{250}$ on any date (Fig. 2). Number of seeds per fruit had a weak positive linear relationship with FW on most dates in both years $\left(R^{2}=0.04\right.$ to 0.12$)$, but seed count was not related to light level (data not presented). When FW was regressed against $\mathrm{CPPD}_{\mathrm{LS}}$, there was still no consistent indication of an influence on FW (Tables 1 and 2).

Imposed-shade treatments (11\% FS) applied to 'Cox' trees for the entire season (Jackson and Palmer, 1977) or to 'Delicious' scaffold limbs ( $<5 \%$ FS) from $\approx 50$ DAFB until harvest (Robinson et al., 1983; Seeley et al., 1980) suppressed apple FW by $66 \%$ and $30 \%$, respectively; $85 \%$ of the variation in FW was explained by light level when data for a single 'Delicious' tree were used (Seeley et al., 1980). The suppression of FW resulted from a reduction in cell count and size (Jackson et al., 1977). Since cell division in apple occurs until $\approx 45$ DAFB (Westwood, 1978), and imposed shade reduced cell count and size, we tested cumulative early season (20 Apr.-5 June) PPD $\left(\mathrm{CPPD}_{\mathrm{ES}}\right)$ as a regressor variable for explaining the variation in FW, but the relationships were not significant (data not presented). Shading within the canopy may not have been severe enough during the early season to influence cell division, or there could have been compensation from other portions of the canopy. The light crop load on our trees may also have been a contributing factor.

Fruit weight suppression in apple due to natural canopy shading has generally been less severe and more variable when compared with suppression in imposed-shade studies (Heinicke, 1966; Morgan et al., 1984; Tustin et al., 1988). This difference is probably the result of compensation or the supply of photosynthates from the better-exposed portions of the canopy, based on Marini et al. (1991), who reported that FW was the quality characteristic of peach that was most influenced by translocated photosynthates from unshaded portions of the tree. Still, suppressions in $\mathrm{FW}$ of $27 \%$ and $31 \%$ were reported for prune (Prunus domestics L.) (Southwick et al., 1990) and 'Delicious' apple (Barritt et al., 1987), respectively, within the canopy.

'Delicious' trees used in our study had relatively open canopies, with light levels at interior positions of our canopies averaging 40 to $65 \mu \mathrm{mol} \cdot \mathrm{m}^{-2} \cdot \mathrm{s}^{-1}$ for hazy or partly cloudy conditions. Jackson (1967) reported that the influence of light levels on 'Cox' FW was enhanced in dense canopies due to reduced light penetration. Yet, within dense 28-year-old 'Starkrimson Delicious' canopies in Virginia, FW was higher for the basal and middle than the terminal portion of lower scaffold limbs in two consecutive years (Marini and Sowers, 1991); also, with fruit from the lower two-thirds of 'Golden Delicious' canopies, a lower percentage of fruit was small than for the upper canopy, which had higher light levels (Ferree, 1989). A higher leaf : fruit ratio as a result of the reduced crop load for the interior canopy (Ferree, 1989) may have compensated for the reduction in light level. Also, differences in the prevalent sky conditions between the arid conditions of the western United States (where most previous studies have been conducted), and the humid conditions in the eastern United States may have contributed to the discrepancy in FW results by influencing can- opy light levels. Lakso and Musselman (1976) demonstrated that light levels were higher at interior positions of apple canopies for hazy and partly cloudy conditions due to increased diffuse light intensities than for cloudless conditions.

Flesh firmness. There was a weak indication of an increase in flesh firmness with increasing $\mathrm{HR}_{250}$ at 135 DAFB in 1990 [Firmness $\left.(\mathrm{N})=77.9+0.02 \mathrm{HR}_{250}, R^{2}=0.11\right]$, and on 165 DAFB [Firmness $(\mathrm{N})=64.7+0.009 \mathrm{HR}_{250}, R^{2}=0.16$ ]. There was, however, no indication of an influence in 1989 or at any other harvest date in 1990. Robinson et al. (1983) reported that flesh firmness was $7 \%$ lower at $100 \%$ FS than at 5\% FS with 'Delicious', and according to Barritt et al. (1987), fruit from the bottom of the canopy were $4 \%$ firmer than those from the top; these differences may have been due to the higher FW of the apples from the higher light intensities. Seeley et al. (1980) and Ferree (1989) reported no effect of imposed or natural light environment (or canopy position), respectively, on flesh firmness.

$L$ : $D$ ratio, starch rating, water core, moldy core. The $\mathrm{L}$ : D ratio was not influenced by any measure of light within the canopy. Rom and Ferree (1984) reported increased L : D ratio on young greenhouse-grown 'Starkrimson Delicious' trees receiving $16 \% \mathrm{FS}$ from budbreak to fruit set compared with nonshaded trees. Robinson et al. (1983) found a $1 \%$ increase in $\mathrm{L}: \mathrm{D}$ ratio of 'Miller Sturdeespur Delicious' with an increase in FS from $5 \%$ to $100 \%$. Apparently, differences in light levels within the canopy were insufficient to influence $\mathrm{L}$ : D ratio under our conditions. Starch rating was not influenced by any measure of light within the canopy under our conditions. Seeley et al. (1980) and Barritt et al. (1987) reported an increase in the starch rating for fruit receiving more light exposure than shaded fruit. Water core and moldy core were not related to canopy light exposure.

Experiment 2. In this experiment, the regressor used to explain the fruit quality measurements was an estimate of the $\mathrm{CPPD}_{\mathrm{LS}}$ based on the percentage value from instantaneous measurements on a single overcast day. The relationships between the estimates of $\mathrm{CPPD}_{\mathrm{LS}}$ and the fruit quality characteristics on the four harvest dates (Table 3 ) were similar to the models from Expt. 1 (Tables 1 and 2). Coefficients of determination were lower for the relationships with PSR and INT, but for SSC, the relationships based on estimated $\mathrm{CPPD}_{\mathrm{LS}}$ values had higher $R^{2}$ than the models from Expt. 1. Therefore, with our experimental conditions, instantaneous light measurements were effective in explaining variation in fruit quality. Instantaneous light measurements offer a great advantage in the saving of time, money, and computer manipulations involved relative to the more detailed light measurements of Expt. 1.

In conclusion, even with detailed cumulative light measurements throughout the entire season, we could usually explain no more than $40 \%$ of the variation in fruit quality characteristics. Even less of the variation could be explained on the later harvest dates. Other factors besides light were responsible for nearly two-thirds of the variation in the fruit quality measures for our conditions.

\section{Literature Cited}

Barden, J.A. 1977. Apple tree growth, net photosynthesis, dark respiration, and specific leaf weight as affected by continuous and intermittent shade. J. Amer. Soc. Hort. Sci. 102:391-394.

Barritt, B.H., C.R. Rom, K.R. Guelich, S.R. Drake, and M.A. Dilley. 1987. Canopy position and light effects on spur, leaf, and fruit characteristics of 'Delicious' apple. HortScience 22:402-405. 
Doud, D.S. and D.C. Ferree. 1980. Influence of altered light levels on growth and fruiting of mature 'Delicious' apple trees. J. Amer. Soc. Hort. Sci. 105:325-328.

Ferree, D.C. 1989. Influence of orchard management systems on spur quality, light, and fruit within the canopy of 'Golden Delicious' apple trees. J. Amer. Soc. Hort. Sci. 114:869-875.

Grappadelli, L.C. and D.C. Coston. 1988. A photosynthetically, active radiation sensor. HortScience 23:215-217.

Heinicke, D.R. 1963. The micro-climate of fruit trees. I. Light measurements with uranyl oxalate actinometer. Can. J. Plant Sci. 43:561-568.

Heinicke, D.R. 1966. Characteristics of McIntosh and Red Delicious apples. as influenced by exposure to sunlight during the growing season. Proc. Amer. Soc. Hort. Sci. 89:10-13.

Heinicke, D.R. 1967. Variations in total and diffuse radiation in relation to cloud cover and its importance on shade in tree canopies. Proc. Amer. Soc. Hort. Sci. 91:113-119.

Jackson, J.E. 1967. Variability in fruit size and colour within individual trees. Rpt. East Mailing Res. Sta. for 1966:110-115.

Jackson, J.E. and J. W. Palmer. 1977. Effects of shade on the growth and cropping of apple trees. II. Effects on the components of yield. J. Hort. Sci. 52:253-266.

Jackson, J.E., J.W. Palmer, M.A. Perring, and R.O. Sharples. 1977. Effects of shade on the growth and cropping of apple trees. III. Effects on fruit growth, chemical composition and quality at harvest and after storage. J. Hort. Sci. 52:267-282.

Lakso, A.N. and R.C. Musselman. 1976. Effects of cloudiness on interior diffuse light in apple trees. J. Amer. Soc. Hort. Sci. 101:642644

Marini, R.P. and J.A. Barden. 1982. Yield, fruit size, and quality of three apple cultivars as influenced by summer or dormant pruning. J. Amer. Soc. Hort. Sci. 107:474-479.

Marini, R.P. and D. Sowers. 1991. Growth, yield, and fruit weight of spur-bound 'Delicious' apple trees following spur-pruning and BA plus $\mathrm{GA}_{4+7}$ application. J. Amer. Soc. Hort. Sci. 116:454-459.

Marini, R.P., D. Sowers, and M.C. Marini. 1991. Peach fruit quality is affected by shade during final swell of fruit growth. J. Amer. Soc. Hort. Sci. 116:383-389.

Montgomery, D.C. and E.A. Peck. 1982. Introduction to linear regression analysis. Wiley, New York. p. 216-243.

Morgan, D.C., C.J. Stanley, R. Volz, and S.I.J. Warrington. 1984.
Summer pruning of 'Gala' apple: The relationship between pruning time, radiation penetration, and fruit quality. J. Amer. Soc. Hort. Sci. 109:637-642.

Patten, K.D. and E.L. Proebsting. 1986. Effect of different artificial shading times and natural light intensities on fruit quality of 'Bing' sweet cherry. J. Amer. Soc. Hort. Sci. 111:360-363.

Proctor, J.T.A. and L.L. Creasy. 1971. Effects of supplemental light on anthocyanin synthesis in 'McIntosh' apples. J. Amer. Soc. Hort. Sci. 96:523-526.

Proctor, J.T.A. and E.C. Lougheed. 1976. The effect of covering apples during development. HortSciencc 11:108-109.

Robinson, T.L., E.J. Seeley, and B.H. Barritt. 1983. Effect of light environment and spur age on 'Delicious' apple fruit size and quality. J. Amer. Soc. Hort. Sci. 108:855-861.

Rom, C.R. and D.C. Ferree. 1984. The influence of light environment early in the season on bloom, fruit development, and return bloom of 'Starkrimson' Red Delicious grown in a greenhouse. Fruit Crops1984: A summary of research. Ohio Agr. Res. Dev. Ctr. Res. Circ. 203:9-16.

Saks, Y., L. Sonego, and R. Ben-Arie. 1990. Artificial light enhances red pigmentation, but not ripening, of harvested 'Anna' apples. HortScience 25:547-549.

SAS Institute, Inc. 1985. SAS user's guide: Statistics, version 5 (ed.). SAS Institute, Inc., Cary, N.C.

Seeley, E.J., W.C. Micke, and R. Kammereck. 1980. 'Delicious' apple fruit size and quality as influenced by radiant flux density in the immediate growing environment. J. Amer. Soc. Hort. Sci. 105:645-647.

Siegelman, H.W. and S.B. Hendricks. 1958. Photocontrol of anthocyanin synthesis in apple skin. Plant Phys. 33:185-190.

Southwick, S.M., S.A. Weinbaum, T.T. Muraoka, W.R. Krueger, K.A. Shackel, and J.T. Yeager. 1990. Leaf attributes as indices of fruit quality in prune tree canopies. HortScience 25:751-754.

Tustin, D.S., P.M. Hirst, and I.J. Warrington. 1988. Influence of orientation and position of fruiting laterals on canopy light penetration, yield, and fruit quality of 'Granny Smith' apple. J. Amer. Soc. Hort. Sci. 113:693-699.

Westwood, M.N. 1978. Temperate zone pomology. W.H. Freeman, San Francisco. p. 199. 